\title{
Real-Time Heart Rate Monitoring for Wearable Electrocardiography Using Filter-Based and Peak Threshold Algorithms: A Comparative Study
}

\author{
Desima Klaudia Hasibuan and Indra Hardian Mulyadi \\ Politeknik Negeri Batam \\ Department of Electrical Engineering \\ Batam Centre, Jl. Ahmad Yani, Batam 29461, Indonesia \\ E-mail: desimahasibuan96@gmail.com
}

\begin{abstract}
Abstrak
Elektrokardiograf (EKG) yang bersifat wearable dan wireless memungkinkan monitoring denyut jantung dilakukan secara real-time dan jangka panjang (24 jam). Beberapa algoritma telah diperkenalkan untuk meningkatkan ketepatan perhitungan denyut jantung untuk diaplikasikan pada EKG jenis ini. Tujuan penelitian ini adalah membandingkan akurasi dari dua buah algoritma perhitungan denyut jantung, yakni Filter-Based dan Peak Threshold. Kedua algoritma ini diimplementasikan ke dalam sebuah prototipe EKG wearable yang berbasis AD8232 dan Mikrokontroler 8-bit (ATMega328), dan Bluetooth. Sinyal EKG dan nilai denyut jantung (dalam satuan Beat per Minute (BPM)) dikirimkan melalui Bluetooth dan ditampilkan secara real-time pada aplikasi Windows yang dibuat menggunakan Visual C\#. Eksperimen dilakukan pada 10 subjek sehat yang berusia tahun $20,4 \pm 2,0$ tahun dan berat badan $60,8 \pm 10,2 \mathrm{~kg}$. Hasil pengukuran dengan menggunakan Filter-Based dan Peak Threshold kemudian dibandingkan dengan EKG wearable komersial (Kinetic $\left.{ }^{\mathrm{TM}}\right)$ sebagai referensi. Hasil pengujian menunjukkan algoritma Filter-Based menghasilkan perhitungan yang lebih akurat dengan Root Mean Square Error (RMSE) 1,53, dibandingkan dengan algoritma Peak Threshold dengan RMSE 2,69.
\end{abstract}

Kata kunci: Elektrokardiograf wearable, Bluetooth, denyut jantung, real-time monitoring, AD8232

\begin{abstract}
Wearable and wireless Electrocardiograph (ECG) enables real-time and long-term monitoring of heart rate (i.e. 24 hours). Several algorithms have been introduced to increase the accuracy of the heart rate calculation for this type of ECG. This study aims to compare the accuracy of two heart rate calculation algorithms: Filter-Based and Peak Threshold. Both algorithms were implemented into a wearable ECG prototype comprising AD8232, 8-bit microcontroller (ATMega328), and Bluetooth. ECG signals and heart rate (in Beat per Minute (BPM)) were sent via Bluetooth and displayed in real-time on a Windows-based application created using Visual C \#. Experiments were conducted on 10 healthy subjects aged $20.4 \pm 2.0$ years and body weight of $60.8 \pm 10.2 \mathrm{~kg}$. The measurement results calculated by using Filter-Based and Peak Threshold were compared to a commercial wearable ECG (Kinetic ${ }^{T M}$ ) as a 'ground truth'. The test results showed that the Filter-Based algorithm resulted in a more accurate calculation with the Root Mean Square Error (RMSE) of 1.53, compared to the Peak Threshold algorithm with RMSE of 2.69.
\end{abstract}

Keywords: Wearable electrocardiograph, Bluetooth, heart rate, real-time monitoring, AD8232

\section{Introduction}

Cardiovascular disease is still the most deadly diseases in the world with 17.3 million of deaths [1]. Roughly 2.6 million people aged over 15 in Indonesia suffer from coronary heart disease [2].

Electrocardiograph (ECG) is a device that is capable to produce electrical signals representing heart activities to monitor heart health [3]. Unfortunately, ECG signals can only be understood by a specialized medical personnel; it is difficult for common users to understand the meaning of signals measured by ECG. For this reason, it is necessary to create a system which is able to process the recorded signal by the ECG automatically into heart rate value, i.e. in Beat per Minute (BPM) which is easier to understand. By using wireless technology, such as Bluetooth, the ECG would be the much easies to use.

One of the challenges in wearable ECGs is their accuracy. Several algorithms have been introduced to increase the accuracy of the heart rate calculation. This study aims to compare the accuracy of two existing

54 | Jurnal Integrasi | Vol.10 No.2, October 2018, 54-58 | e-ISSN: 2548-9828 
RA, LA, RL

Wet Electrodes

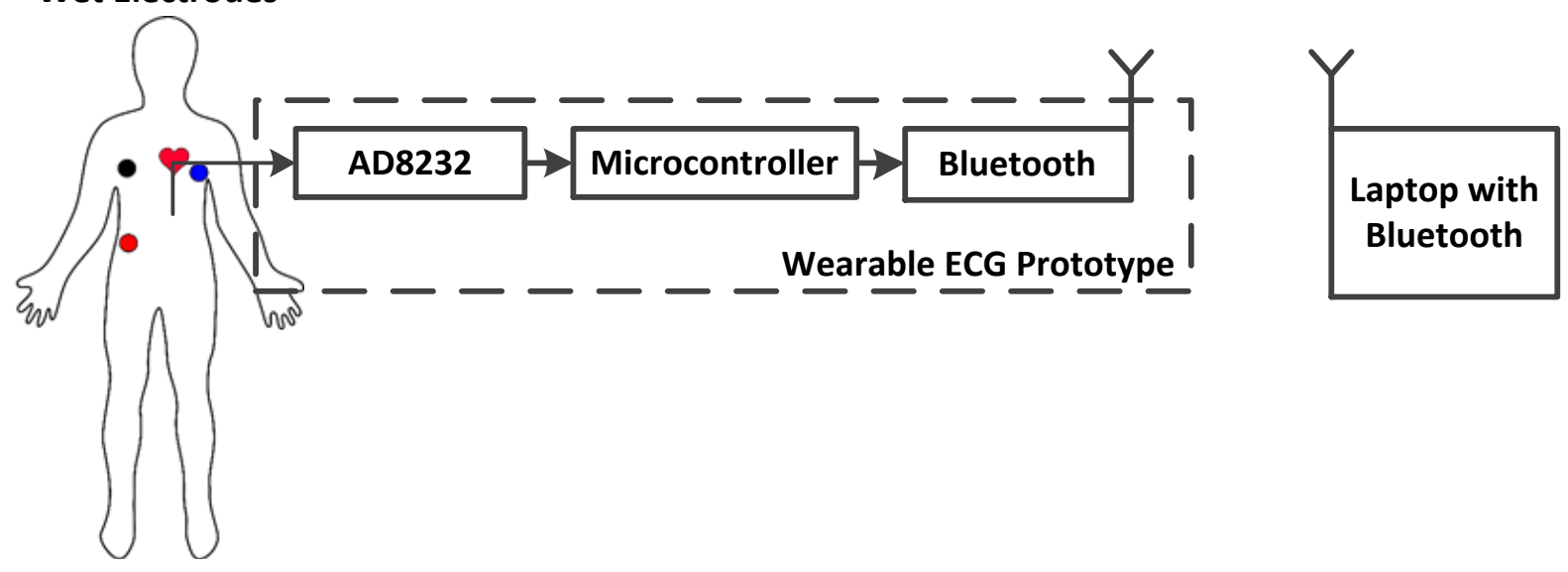

Figure 1: System block diagram

heart rate calculation algorithms: Filter-Based and Peak Threshold, as well as build a wearable ECG prototype and a Windows-based real-time heart monitoring application.

\section{Method}

\subsection{Proposed System}

The proposed system is described in system block diagram as shown in Figure 1. The wearable ECG prototype comprises a single-channel bio-potential amplifier (AD8232), an 8-bit Microcontroller (ATMega328 in Arduino Nano module), and Bluetooth (in HC-05 module). AD8232 was used to acquire ECG signal, digitized it, and sent the digital data to ATMega328. ATMega328 processed the data, i.e. filtering and calculating heart rate, and then sent the processed data to laptop via Bluetooth. The data (ECG signal and heart rate) were then displayed in laptop on Windows-based application built by using Microsoft Visual C\#.

Heart rate value in BPM was calculated by measuring $\mathrm{RR}$ interval, i.e. interval between two consecutive $\mathrm{R}$ peaks. In this study, we detected two QRS-complex signals in real-time and measuring RR interval based on those signals. After that, we calculated the heart rate $H R$ (in BPM) by using (1), where $R R_{-}$Interval is time interval between two consecutive $\mathrm{R}$ peaks in $\mathrm{ms}$ :

$$
H R=\frac{60000}{R R_{-} \text {Interval }}
$$

In this study, we compared two algorithms to detect QRS-complex and calculate the heart rate: Filter-based and Peak Threshold. The algorithms are explained as follow:

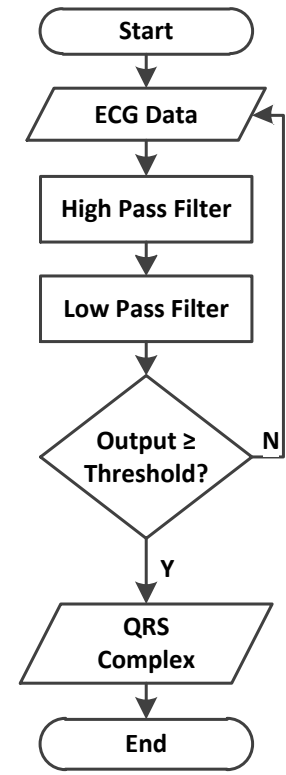

Figure 2: Filter-based algorithm

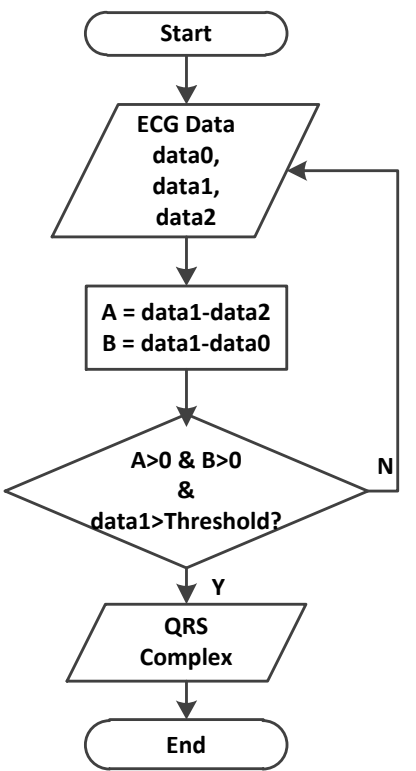

Figure 3: Peak threshold algorithm 


\subsection{Filter Based [4]}

This algorithm consists of three main stages: High Pass Filter (HPF), Low Pass Filter (LPF), and Decision Making (DM). The HPF utilizes a linear system consisting of M-point Moving Average Filter (MAF) and group delay system of $(M+1) / 2$ samples. The MAF output is then subtracted by the point-by-point of the delayed input sample, so that the whole system becomes Finite Impulse Response (FIR) HPF with linear phase. In this case, $\mathrm{M}$ is limited to odd values, e.g. $M=5$ or $M=7$. The calculation is shown in (2), where $x[n]$ is input data of sample $n, y[n]$ is output, $M$ is the filter length.

$$
y[n]=x\left[n-\frac{M+1}{2}\right]-\frac{1}{M} \sum_{m=0}^{M-1} x[n-m]
$$

The output of the HPF is become input of nonlinear LPF which consists of squaring and moving window integration as calculated in (3). Based on previous research, the value of $K$ was set to 30 for $200 \mathrm{~Hz}$ sampling rate [5].

$$
z[n]=\sum_{k=0}^{K-1} y^{2}[n-k]
$$

Finally, the DM stage determines the QRS complex of the ECG signal. Adaptive threshold in (4), (5), and (6) were used for this purpose. $P E A K$ is new local maxima, $\alpha$ is "forgetting factor" $(0 \leq \alpha \leq 1)$, and $\gamma$ is weighting factor, which is used for the contribution of peak values for adjusting the determination of the threshold. Empirically, $\gamma$ range is 0.15 to 0.2 .

$$
\begin{gathered}
\text { if } z[n] \geq \text { Threshold } \rightarrow \text { QRS complex } \\
\text { if } z[n]<\text { Threshold } \rightarrow \text { NOT QRS complex } \\
\text { Threshold }=\alpha \gamma P E A K-(1-\alpha) \text { Threshold }
\end{gathered}
$$

\subsection{Peak Threshold [6]}

In this algorithm, a data point $x_{n}$ is considered as $\mathrm{R}$ peak of the QRS complex if the current point $x_{n}$ subtracted by the previous data point $x_{n-1}$ is positive, the current data point $x_{n}$ subtracted by the next data point $x_{n+1}$ is positive, and at the same time, the current data point $x_{n}$ exceeds the specified threshold value. Please refer to Equation (7), (8), and (9).

$$
\begin{gathered}
x_{n}-x_{n-1}>0 \\
x_{n}-x_{n+1}>0 \\
x_{n}>\text { Threshold }
\end{gathered}
$$

\subsection{Experiment Setup}

We tested system with two algorithms to ten healthy subjects, aged 20.4 \pm 2.0 years and weighed $60.8 \pm 10.2$

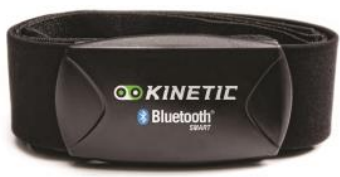

Figure 4: Kinetic ${ }^{\mathrm{TM}}$ Dual Band Heart Rate Strap

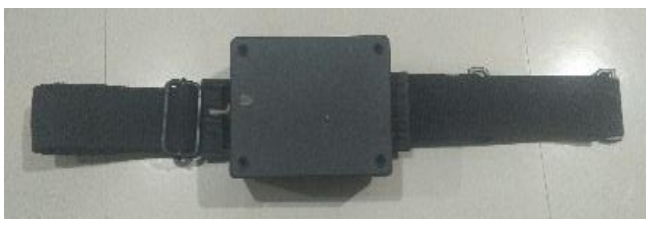

Figure 5: The wearable ECG prototype

$\mathrm{kg}$. Measurement of each subject was conducted for five times. A commercial dual band heart rate strap, namely Kinetic ${ }^{\mathrm{TM}}$ (Figure 4) was used as the 'ground truth'. Performance of the algorithms was measured by using root mean squared error (RMSE) as described in (10), where $V_{\text {Prototype }}$ is heart rate measured by using our prototype, $V_{\text {Kinetic }}$ is heart rate measured by using Kinetic $^{\mathrm{TM}}$, and $N$ is number of experiments, i.e. five. ECG signal was the displayed in GUI as well as heart rate (in $\mathrm{BPM}$ )

$$
R M S E=\sqrt{\frac{1}{N} \sum_{i=1}^{N}\left(V_{\text {Prototype }}-V_{\text {Kinetic }}\right)^{2}}
$$

\section{Result and Discussion}

\subsection{System Test}

Based on the performance test, our system (the prototype (Figure 5) and the Windows-based real-time heart rate monitor application (Figure 6)) worked well. The ECG signal was displayed in real-time as well as calculated heart rate. The 8-bit microcontroller was able to calculate heart rate using Filter-Based and Peak Threshold algorithms. Bluetooth in baud rate of 115200 bit per second (BPS) was sufficient for this application. However, the system was tested just in several minutes, while 24-hours testing should be performed for real application.

\subsection{Algorithm Performance Test}




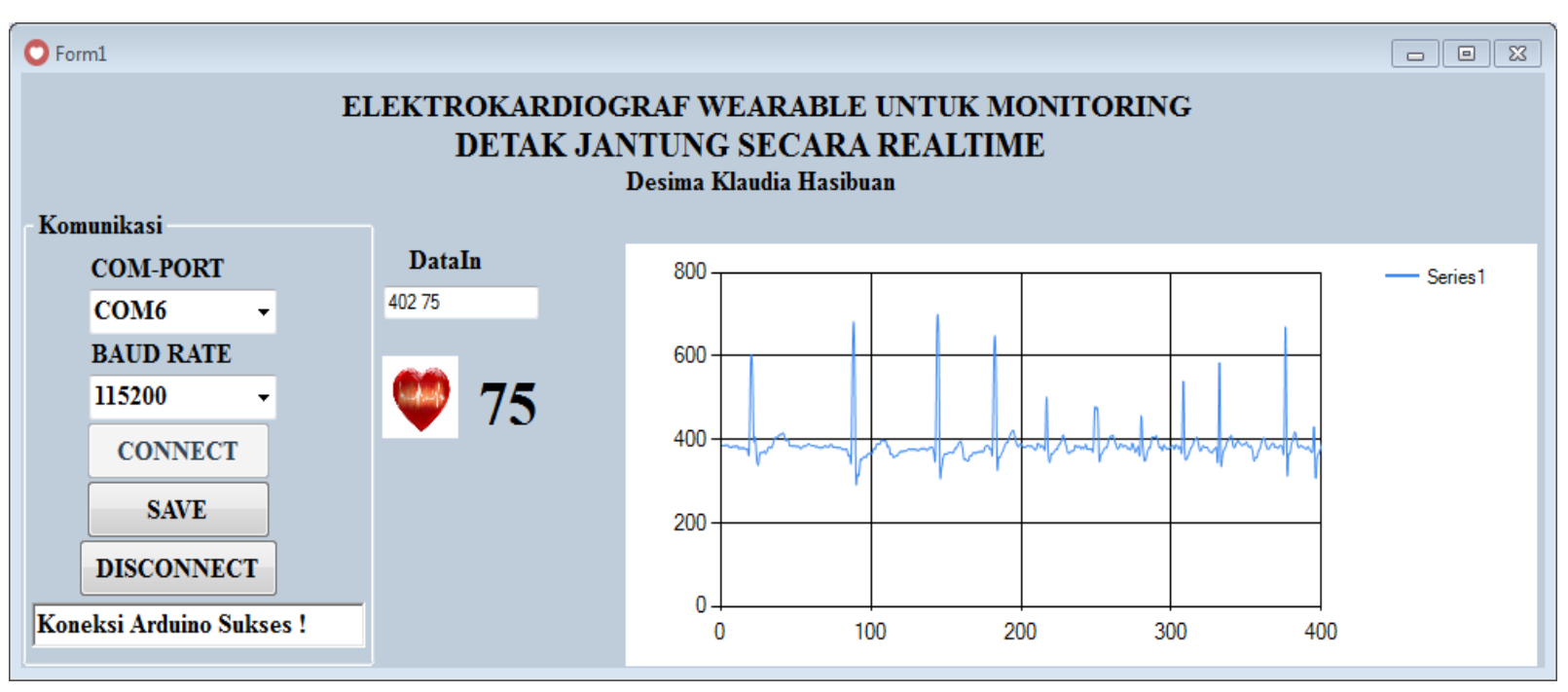

Figure 6: Snapshot of the GUI

TABLE I

HEART RATE (IN BPM) CALCULATED BY ECG PROTYPE (FILTER-BASED ALGORITHM) AND KINETIC ${ }^{\text {TM }}$.

\begin{tabular}{|c|c|c|c|c|c|c|c|c|c|c|c|}
\hline Experiment & & st & & nd & & rd & 2 & & & th & \\
\hline 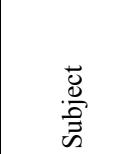 & 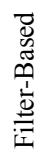 & $\begin{array}{l}\sum_{0} \\
.0 \\
.0 \\
.0\end{array}$ & 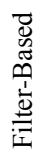 & 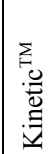 & 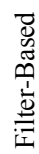 & $\begin{array}{l}\sum_{0}^{0} \\
.0 \\
.0 \\
.0\end{array}$ & 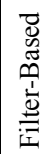 & 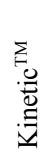 & 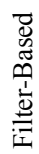 & $\begin{array}{l}\sum_{0} \\
.0 \\
.0 \\
.0\end{array}$ & RMSE \\
\hline 1 & 70 & 70 & 76 & 77 & 79 & 80 & 69 & 71 & 72 & 72 & 1.10 \\
\hline 2 & 99 & 100 & 99 & 100 & 99 & 101 & 101 & 103 & 98 & 101 & 1.95 \\
\hline 3 & 72 & 75 & 82 & 84 & 79 & 79 & 86 & 84 & 88 & 86 & 2.05 \\
\hline 4 & 74 & 76 & 79 & 77 & 75 & 74 & 71 & 73 & 78 & 80 & 1.84 \\
\hline 5 & 93 & 94 & 93 & 93 & 91 & 91 & 100 & 99 & 99 & 99 & 0.63 \\
\hline 6 & 78 & 76 & 70 & 72 & 74 & 71 & 67 & 70 & 80 & 80 & 2.28 \\
\hline 7 & 81 & 79 & 75 & 74 & 78 & 77 & 85 & 84 & 87 & 87 & 1.18 \\
\hline 8 & 72 & 73 & 70 & 70 & 75 & 77 & 71 & 69 & 73 & 71 & 1.61 \\
\hline 9 & 80 & 77 & 73 & 73 & 75 & 74 & 71 & 71 & 72 & 72 & 1.41 \\
\hline 10 & 58 & 58 & 69 & 67 & 64 & 64 & 64 & 62 & 64 & 64 & 1.26 \\
\hline \multicolumn{11}{|c|}{ RMSE Average } & 1.53 \\
\hline
\end{tabular}

TABLE II

HEART RATE (IN BPM) CALCULATED BY ECG PROTYPE (PEAK THRESHOLD ALGORITHM) AND KINETIC ${ }^{\text {TM }}$.

\begin{tabular}{|c|c|c|c|c|c|c|c|c|c|c|c|}
\hline Experiment & \multicolumn{2}{|c|}{$1^{\text {st }}$} & \multicolumn{2}{|c|}{$2^{\text {nd }}$} & \multicolumn{2}{|c|}{$3^{\text {rd }}$} & \multicolumn{2}{|c|}{$4^{\text {th }}$} & \multicolumn{2}{|c|}{$5^{\text {th }}$} & \multirow[b]{2}{*}{ RMSE } \\
\hline 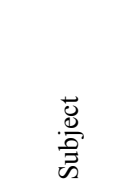 & 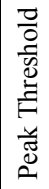 & 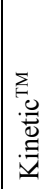 & 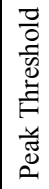 & 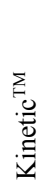 & 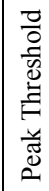 & 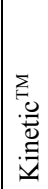 & 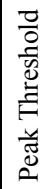 & 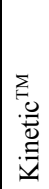 & 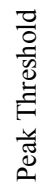 & 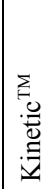 & \\
\hline 1 & 77 & 73 & 77 & 73 & 79 & 78 & 78 & 79 & 76 & 76 & 2.61 \\
\hline 2 & 103 & 110 & 103 & 100 & 103 & 102 & 103 & 107 & 106 & 107 & 3.9 \\
\hline 3 & 82 & 84 & 80 & 79 & 81 & 81 & 93 & 87 & 81 & 81 & 2.86 \\
\hline 4 & 78 & 76 & 80 & 77 & 65 & 69 & 73 & 75 & 67 & 72 & 3.41 \\
\hline 5 & 105 & 98 & 96 & 95 & 101 & 98 & 103 & 104 & 92 & 91 & 3.49 \\
\hline 6 & 72 & 72 & 88 & 86 & 71 & 74 & 78 & 78 & 71 & 71 & 1.61 \\
\hline 7 & 84 & 80 & 69 & 76 & 91 & 86 & 83 & 79 & 76 & 77 & 4.63 \\
\hline 8 & 80 & 80 & 82 & 85 & 79 & 78 & 74 & 75 & 80 & 80 & 1.48 \\
\hline 9 & 70 & 71 & 73 & 71 & 75 & 71 & 71 & 71 & 71 & 73 & 2.24 \\
\hline 10 & 58 & 57 & 58 & 59 & 59 & 59 & 56 & 56 & 63 & 63 & 0.63 \\
\hline \multicolumn{11}{|c|}{ RMSE Average } & 2.69 \\
\hline
\end{tabular}

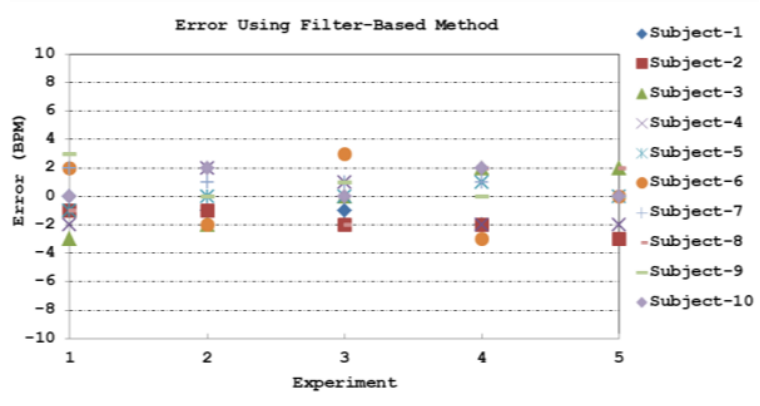

Figure 7: Error resulted by Filter-based algorithm

Performance of Filter-Based and Peak Threshold algorithms are presented in Table I and Table II. Figure 7 and 8 illustrate the error of each experiment for each subject. Based on the performance test results, we

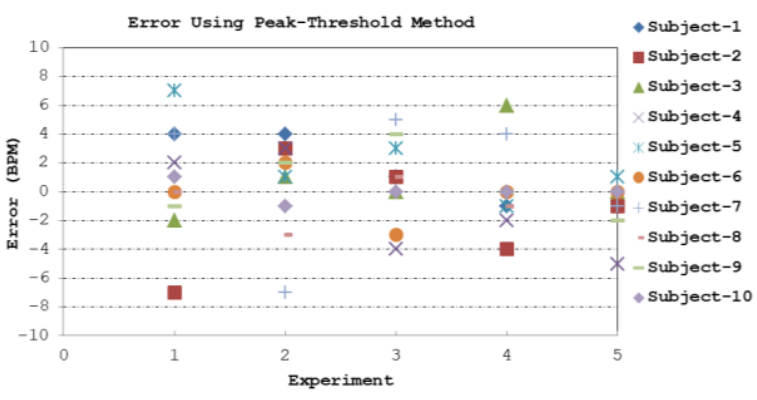

Figure 8: Error resulted by peak threshold algorithm

conclude that Filter-Based algorithm outperformed Peak Threshold, with RMSE of 1.53 and 2.69, respectively. Hence, Filter-Based algorithm is recommended to be utilized for this application. 


\section{Conclusions}

A real-time wireless heart monitoring comprising wearable ECG and Windows-based application have been built and worked well. Based on our performance tests, Filter-Based outperformed Peak Threshold algorithm with RMSE of 1.53 and 2.69 , respectively. Our future work would be implementing this system into real application, i.e. 24-hours monitoring.

\section{Acknowledgment}

This work was supported by Directorate of Research and Community Engagement, Indonesian Ministry of Research, Technology and Higher Education (Grant no: 018/SP2H/LT/DRPM/2018).

\section{References}

[1] Emelia J. Benjamin et al., "Heart Disease and Stroke Statistics-2017 Update: A Report From the American Heart Association," American Heart Association, 2017.

[2] Pusdatin, "Info Data: Situasi Kesehatan Jantung," Kementrerian Kesehatan Republik Indonesia, Jakarta, 2014.

[3] Jakko Malviuo and Robert Plonsey, Bioelectromagnetism-Principles and Applications of Bioelectric and Biomagnetic Fields. New York: Oxford University Press, 1995.

[4] H.C. Chen and S.W. Chen, "A Moving Average based Filtering with its Application to Reak-time QRS Detection," in Computers in Cardiology, Thessaloniki Chalkidiki, 2003, pp. 585-588.

[5] J. Pan and W. J. Tompkins, "A Real-Time QRS Detection Algorithm," IEEE Transactions on Biomedical Engineering, vol. BME-32, no. 3, pp. 230-236, March 1985.

[6] Trio Pambudi Utomo, Nuryani Nuryani, and Darmanto, "QRS Peak Detection for Heart Rate Monitoring on Android Smartphone," Journal of Physics: Conference Series, vol. 909, no. 1, pp. 1-7, 2017. 